\title{
The Role of Civil Society in Preventing Global Poverty
}

Özet

Osman TEKİR

20. yüzyılın ikinci yarısında, özellikle 1980'lerden itibaren, "küreselleşme" ve "sivil toplum" üzerindeki tartışmalar akademik ve günlük hayatımızın önemli boyutunu oluşturmaya başlamıştır. Küreselleşme ile birlikte sivil toplum kuruluşlarının gerek yerel düzeyde gerek uluslararası alanda oynadıkları roller önem kazanmıştır.

Bu çalışmada önce "sivil toplum" ve "küresel sivil toplum" kavramları açıklanmış, daha sonra yoksulluğun önlenmesinde bu kuruluşların oynadıkları roller ele alınmaya çalışılmıştır. Çalışmanın sonunda da potansiyel olarak bu kuruluşların görevlerini yerine getirirken karşılaşabilecekleri sorunları ve bu sorunlara yönelik olası çözüm yolları üzerinde durulmuştur.

Anahtar kelimler: Sivil toplum, küreselleşme, küresel sivil toplum. yoksulluk

Abstract

In the second half of 20th century, especially since 1980s, the discussions over "globalization" and "civil society" started to constitute important dimension of our daily and academic life. The role of civil society organizations have gained significance locally and globally.

In this paper, the concepts of "civil society" and "global civil society" are explained and then, the roles of these organizations in preventing poverty are analyzed. At the end of the study, the problems that civil society organization might encounter and possible recommendations to these problems are addressed.

Key words: Civil society, globalization, global civil society, poverty.

\section{Concept}

There are many different definitions related to the concept of "globalization". The most widely used one is that globalization can be detected as to set up links between people wherever they live on our planet . To increase the global connections among the people; to be able to make connections with the people all over the world in human, technological, legal, cultural, economic and psychological sense, indicates that we are living in the same planet. (Sholte,2005:1).

On the other hand, Civil society concept in the context of the present liberal values, could be defined as the institutions and activities created

*Yrd. Doç. Dr. Uşak üniversitesi, İktisadi ve İdari Bilimler Fakültesi 
outside the areas directly controlled by the state and relatively independent of the pressures of the economic relations but formed through the relations based on voluntarily and consent (Duman, 2007:357).

During the 1970s and 80s, when the idea of civil society is reconsidered, its governmental ties have been increasingly weakened. While the civil society idea in Latin American countries has developed on the basis of Marxist ideology, in East European countries the course of development of this idea grew in the anti-Marxist ideological line. But in both cases, it is said that the civil society has always been in the attitute of being against military regimes.

In the literature, depending on the intense effects of the globalization, we can see that the revival of civil society movement has reemerged in two different ways. One of them, especially in the process of neo-liberal globalization, is in parallel with the revival of civil society following the decline of state's capacity in solving the problems of community welfare, economic development, environmental and social issues, And the second one is that in the 1980s and 1990s the basic social issues from the economic to environmental issues, and from the basic human rights to the cultural identity claims, even these are seen at local and national level, had gained a global significance (Keyman, 2005:16).

Since the mid 19th century, global civil society that is increasingly seen in the political arena had entered into the social life as a political actor after 1945. It is claimed that global non-governmental organizations could contribute to the creation of a global culture in five different aspects. These are: 1. Universality. people in everywhere have similar needs and desires. 2. Individuality. The members of the many of the global non-governmental organizations are individuals or the persons representing associations. The structure of their decision making mechanism resembles individuals. 3. Acting in a collective mind. They usually possess a collective political action according to the principles put forward on the basis of individual responsibility. 4. Rationality, realism is the main moving point in their actions. 5. World citizenship. Although the individuals carry some differences in their capacity, resources, and intelligence, they might have the same rights and obligations. With these natural aspects, it should be noted that in the parallel of world wide European Enlightment principles, global civil society means all kind of Western nation-states' institutional changeinnovation, law based public administration and some sort of consensus among the voluntary organizations (Coleman and Mayland, 2006:242-243).

When the global issues such as climate change, financial market stability and the protection of human rights etc. arose, the governments 
always support their own internal organizations to become organized at global level. To protect the collective interests of human being, the governments can create on one hand, some international institutions and on the other hand, they may also want to create their own source of information and to maintain their legitimacy as well. These global civil societies will have a strong network to make international connections with the governments and international organizations. These networks are becoming so powerful that the political preferences of states at the national level can sometimes take on a kind of blocker (Coleman and Mayland, 2006:244).

\section{Global Civil Society in the Prevention of Poverty}

Besides the lack of income and resources, it can be said that the poverty which also means lack of opportunities can occur in many different ways and can cause very severe social damages. Because of some reasons such as geographical and social exclusion and inadequate education, for the poor people it is difficult to be able to have the means of access to markets and job opportunities. Malnutrition, and lack of hygiene and health services can cause physical and mental loss in this part of society. Also the absence of any eduquate insurance system against unexpected incidents deteriorates the social conditions (The World Bank, 2000:2).

Today it is well known that the number of people living in conditions mentioned above is quite a lot. Because, about one sixth of world population, according to data of World Bank 2004, with only one dolar income a day and less than two million people with less than two dollars income a day are trying to survive (The World Bank, 2004:3).

According to the 2007 World Development Report, which is used as a valuable source in determining the poverty line, indicates that the economic development in the world could not be sufficient for the poor people to provide a normal standart of living, the income gap among the countries is always increasing and the poverty all over the world is growing. According to that report, around 2.8 billion people with less than two dollars a day try to keep themselves alive; and one forth of the world population, or about 60 percent remaining, with less than two dollars a day are living under the poverty line conditions.

Moreover, according to the statistic of FAO, approximately 925 million people experince malnutrition in 2010. The number of hungry people was 850 million between 2006-2008 (FAO:2012). The data, thus, indicate that the number of poor people has increased since 2008.

When a poverty problem emerges in anywhere in the world, the instant effects of it at first are felt at local level and remain local, but 
nowadays the effects of that problem are being felt at global level and threatining the world peace (Onen, 2008:456).

Today, fighting against poverty is more than a simple satisfaction of the moral and personal responsibilities, it is becoming an issue of global peace and there is really a need for the elimination of poverty to maintain the global stability. Poverty is not a specific problem for the developing countries, rather as an element of mutual international assistance it is really a very important for ensuring global peace and prevention of migration. While poverty leads to the increase of global violence and unrest, the wars also lead to more and more deep poverty. International NGOs, as a result of the globalization, with their ability to possess a worldwide organizational effectiveness, and their ability to adapt themselves to changing conditions and to have expertise in their topics and global issues, have very significant functions in dealing with global issues. International NGOs, in an environment in which traditional boundries lost their importance and statecentered approaches were thrown aside and a phenomenal growth area developed outside the state, have gained central role and effectiviness in the international field beyond the national borders(Karagül, 2008).

In 2001, the former Secretary general of the United Nations Kofi Annan, had given a description and identification for the globalization. To him, today, unlike in the past, individuals and groups outside the government are developing more relations among each other and crossborder cooperations. The main motive of these achivements is to have ability to combine their efforts in the framework of developments in the information technologies

Globalization, of course, is getting many benefits such as raising living standards, and creating new facilities and opportunities. However, these benefits of globalization are not evenly and sufficiently distributed. Because, rich and poor are to compete each other in the same global market and in this situation the exploitation of the poor is remaining unchanged.

Nations, within the framework of the shared values and rules, are attending more efficiently in the globalization process. The governments will not be able to achive this themselves alone, so the private sector and the voluntary organizations will have to contribute to this process. Annan insisted that until 2015 the world leaders would have to deal with these three basic issues.

First, to improve the living conditions of the people who have one dolar income a day; secondly, to produce a solution for the elimination of poverty and hunger; and thirdly, to ensure reliable water sources. In doing 
these important responsibilities, NGOs will have to make great contributions(Annan, 2001:84).

At the beginning, when the most important developments and progress occuring in the economy is being welcomed, then it is seen that this process will bring about some fundamental issues. Economic disparities emerging between the developed North and the underdeveloped South have caused the gap to increasingly grow and global imbalances and differences in poverty to increase. Multi-national corporations that are the most important actors in the economic globalization might have negative effects on the nation-states and national economies in both economic and political fields. That is one of the negative effects arising from globalization.

It is accepted that to erase these disadvantages, civil society should undertake vital functions. Some NGOs which is active in European scale have taken on really important responsibilities in eradicating the poverty and social exclusion. The EANP (European Anti-Poverty Network) defined its own objectives as that to keep the poverty and social exclusion issues constantly on the agenda, to ensure to take the effective measures to combat these problems, to make lobbying with groups facing with such a danger. FEANTSA (Federation Europenne d'Associations Nationales Travaillant Avec Les Sans-Abri) as an umbrella organization bringing together 90 national non-governmental organizations and acting for particularly on homelessness issues in 25 European countries explains its purpose of establishment as to remind their responsibilities to the politicians and to monitor them whether they are fulfilling these responsibilities or not and to influence the formation of social policies (Bob,2005:14-15).

Since the early 1990s' in some studies on OECD countries it is claimed that particularly global markets and global productions reduced the social cohesion in the society and led to the emergence of new problems. Widespread increase of particular socio-economic inequalities caused the increase of social polarization and led to changes in lifestyle and values. Individuals are felt compelled to fit themselves to new environment that is being created by globalization. There might be two important answers to this problem: First, individuals must have a strong sense of social responsibility in the society and should strive to resolve these social deficiencies. Second, existing and potential partnerships should be established to solve the problem (Helly, 2003:21).

When the society faced structural inequalities, a new justice system will be needed. It is called as social integration. For example, from the socioeconomic point, to create jobs for those who unemployed and to find some solutions to the family problems. For these reasons, some measures are 
taken to resolve the lack of public policies through the reformations and democratization. In this democratization process, citizens are being strengthened by developing partnerships among the public and private sectors (social groups, individuals, NGOs, etc.). This is very important for all segments of society. Because, the increase of the effects of public policies at local level will also increase social compliance in the society.

NGOs today have a very dynamic character, and even in conflicting interests they can create cooperation and reconciliation. Whether it is desired or not, as a part of civil society, the effectiveness of NGOs are increasingly growing. The autonomy of civil society becomes more and more complex and differenciated, depending on governmental control on them, its level of autonomy is decreasing or increasing. If the citizen is in the active position and will take a contributive role in this process the state power may become invisible. When the concept of politics is associated with the democratization, even if the power is shared with individuals contributing and taking responsibility, the governments can not gain a decision-making position in the country (Helly, 2003:22).

Liberals and conservatives have claim that globalization makes our age gradually improved on the basis of civil society. Liberals have expressed that in solving the human rights and environmental problems the importance of the effectivenes of NGOs is inevitable. To the Conservatives, the effects of globalization on the development of democracy should be based on civil society. NGOs defined as civil society, rather than the actual factor in developing democratic culture, they are the main instruments of democracy. (Kamat, 2003:65).

NGOs resulting from strengthening the civil actors of the society are contributing to the democratization, in this context, they are also giving profesional support to the governmental institutions in improving the citizens' awarenes and in eradicating poverty. By using the projects at local level and increasing the capacity of individuals they are able to save the poor people from the poverty. They are also able to increase the social efforts related to the citizens' awarness, the determination of the poverty problems and their solutions.

Democratic quality of cosmopolitan thought can be sustainable by global civil societies's civility. As a principle, international nongovernmental organizations (INGOs) are very important means of representation and responsibility of any individual society. Instead of debates of acts and different kinds of unseen represented thoughts and interests of NGOs, they are still a very powerfull pressure groups on global governance and also their actings are justifiable at people hands. Global civil 
society which is persuading powerful one to powerless of society, is continuing in a concilliation manner (Smith and Brasset, 2008:81-82).

As very active organizations, NGOs have very important roles to make weak people cosciousness who are more vulnerable so the people can defend their rights. The relationships are being establihed between the new economic institutions and the NGOs have given power to the people who have suffered by poverty organise by themselves as opposed to the state and especially state elites. This is a very important case for capitalist economies in which the poverty can be reduced and also the individuals can make their developmental potentials to live by themselves. According to World Bank, one of the importance of reducing poverty is to make poor pople to be powerfull in order to live by themselves so they will participate on governing process. By doing this both private sectors and governmental sectors and donors will know what and how they will help the poverty to be reduced. As result of this, citizens will be active individuals by participating on decision making process to make democracy more sustainable(Kamat, 2003:68).

The meaning of microcredits is to make NGOs powerfull and to reduce government responsibility. Having NGOs capacity developed many projects, programs and plans are activitated in order to reduce poverty in developing and underdevelopled countries. The more economically powerfull the poor people, the more their life standarts are increasing. Microcredits are also important for neo-liberal programs sustainable. In this case the risks are reduced at poor hands by making them living in a better conditions. This case also helps poor people to develop their capacities psychologically and trust each other in society at global level. So by giving microcredits, human capital is being used in a very valuable manner. In a competitive society the people who compete with each other to make their individuals identities better and to develop their capacities resulting in reducing inequalities of social life (Kamat, 2003:69). On the one hand, the prosperity will be developed in society and on the other hand, democracy will be sustainable in any individual soiety in this manner.

\section{Basic Problems}

Up to now it is stated that civil organizations have important roles supporting people in global process. However civil organizations have faced some problems in order to act their goals and aims. In this part of the paper ,these problems will be disccussed.

The problem of global civil society has two causes. In the first one is to relate how and to whom the global civil society will serve. And secondly, 
because of the problems have been solved by global actors in a global manner, the actors act according to whom, and also how they will solve the problems must be questionable. From local level to national, the political actors and civil organizations have addressed in a national level will be unseen in international level (Baker, 2002.928). So it can be arguable that INGOs problem basically come either from its sturucture also from its acting.

According to Baker, (Baker,2002:936) the main goals of global civil society is to make western society's hegemonic power to other countries. In another words, global civil society is composed of western hegemonic power. This will rise to global conflicts in global society. In terms of these problems, global organizations are being supported by western powers will not be happened at the rest of the world. In another words, except of western base how the civil organizations will be defined as global if the western civil organizations have supported by western governments. Moreover the other main problem for INGOs is the structure of global organizations. Because of the global organizations established without any election, the problem is occuring from whom they represent and from which identities and cultural values the have. Even though they are voluntary organizations, they have stil religious, ethnic, ideologic and economic values and norms for his reason, it is important to know whom they represent and why and how they act. As a result, although the global civil organizations give cosmopolitan civil identities the people who loose their values under nations, how these powers they get and for what reason they use like this still questionable. Because of this antidemocratic character of global civil society it also causes to global conflict as a whole.

Moreover Köhler is stating that the global organizations are mediators in international relations in which they play lots of functions in between global actors and any individual country (Baker, 2002:936, quoted in Köhler, 1998:245). Baker this is true he told but he make improve by evaluating civil society at global manner and conclude that when civil society is being global, the nation-states's sovereignity would be loosed. This is also another big problem for global civil society being defined or not as authoritarianism(Baker,2002:937).

Another problem for global organizations is mainly financial. Their actings are being paid by global actors or the global actors support global organizations (as a voluntary) in order to manage their goals and aims. So there would be a very close interest relations between civil organizations and global actors. This case will make civil organizations financially, 
ideologically and other kinds (in what kind of relations between them) be dependent on global actors or any individual state (Ateş, 2006:25-38).

To conclude, the civil organizations have generally been discussed related to their structures and actings. However, in order to define the structure and the act of civil organizations in that the goals of them must be designed by themselves. When their goals and aims must be defined and determined by other persons, political, religious, cultural, identity or financial actors as a global actor then the civil organization will not be civil as compared to its establishment. This is especially important if a private sector or a state wanted to fiance a civil organizations actings to manage. In that sense civil society organizations realize other powers' aims by being diverted from their own goals.

If the civil society is a good actings in terms of their establishments, then the organizations of society will be for itself. This will help individuals to participate decisions making process and also press decision process preventing poverty and causing democracy sustainable and widespreaded.

Civil society is not a miracle to solve all problems we have faced as a human beings, If we have such perspective, then civil organizations would be untrust and futility organizations. However, if every solution can be given to civil organizations by making stronger of them then civil organizations can have authoritarian power causing antidemocratic values and may destroy democracy in general.

Shortly, it can be stated that the civil organizatios' effectiveness in any individual society and to serve as it is depend on their legitimacy in society, states must eliminate barries of civil organizations in society.

\section{References}

Ateş, D. (2006). Küreselleşme:Ne Kadar boyutlu?. Doğuş Üniversitesi, 7 (1).

Baker, G. (2002). Problems in the Theorisation of Global Civil society. Political Studies, Vol. 50.

Buğra, A. (2005). Yoksulluk ve Sosyal Haklar. Sivil Toplum Geliştirme Merkezi, İstanbul.

Coleman, D. William and M., Sarah (2006). The Origins of Global Civil Society and Nonterritorial Governance: Some Emperical Reflections Global Governance, 12.

Duman, F. (2007). Sivil Toplum, Siyaset, Ed: Mümtaz'er Türköne, Lotus Yayınevi, 5. basım, Ankara.

FAO. (2012) retrieved from

"www.worldhunger.org/.../world\%20hunger\%20facts\%202002.htm".

12.january 2012.. 
Helly, D. (2003). Social Cohesion and Cultural Plurality. (Robert F. Barsky and Patricial Foxen, Trans.) Canadian Journal of Sociology, 28, 1.

Kamat, S.. (2003). NGOs And the New Democracy. Harvard Int.

Karagül, S. (2008). Küresel Bir Aktör Olarak Uluslar arası Sivil toplum Kuruluşları.

Retrieved

from:http://www.turkishweekly.net/turce/makale.php?id-111,

Keyman, F. (2005). Küreselleşme ve Sivil Toplum. Sivil Toplum ve Demokrasi Konferans Yazlları. (No 10). İstanbul Bilgi Üniversitesi Sivil Toplum Kuruluşları Eğitim ve Araştırma Birimi.

Önen, M. (2008). Küresel Barış İçin Yoksulluğun Azaltılması ve Türkiye. V. Uluslarası STK'lar Kongresi. (24-26 Ekim). Onsekiz Mart Üniversitesi, Çanakkale.

Sholte, J. A. (2005). Küreselleşme ve Sivil toplum. Sivil Toplum ve Demokrasi Konferans Yazıları. (N0 10). İstanbul Bilgi Üniversitesi Sivil Toplum Kuruluşları Eğitim ve Araştırma Birimi.

Smith, W. and B., James. (2008). Deliberation and Global Governance:Liberal, Cosmopolitan and Critical Perspectives. Ethics and International affairs.

The World Bank. (2000). Global Poverty Report. G8 Okinava Summit.

The World Bank. (2004). World Development Indicators 2004. 